\title{
13 How crowds transform identities
}

\author{
Yasemin Gülsüm Acar and Stephen Reicher
}

\section{Introduction}

In this chapter we address the role of crowd events in reshaping the boundaries of group inclusion and exclusion. In this way we hope to shed some new light on the process of reconciliation - of how it can be facilitated and how it can be undermined through the dynamics of mass action.

Empirically, our discussion is based on two major events in the recent history of Turkey, both of which were centred on the question of the nature of Turkish nationhood. We start with the 2013 Gezi Park protests which sought to assert a new vision of Turkey and, in so doing, brought together groups who, previously, had been deeply (and, at times, violently) opposed. Kurds stood side by side with nationalist Turks, even after decades of assimilationist policies and conflict, Alevis with Sunnis, despite discrimination and violence, and LGBT activists, who were often maligned and marginalized by any or all of these groups. We then turn to the post-2016 coup "Democracy Watches" gatherings, which also brought people together under the badge of nationhood but which excluded many, such as the Kurds, who were defined as a threat, as were those who sympathized with them - or at least opposed repressive measures being taken against them. This contributed to both the deepening and the broadening of conflict, where previously there had been a process of reconciliation.

At first glance, it might seem rather strange to address the issue of reconciliation through the prism of crowd psychology, and even stranger to suggest that crowds might be a resource for reconciling opposed groups. After all, crowds are traditionally associated with chaos and discord. According to Gustave Le Bon's (1895) classic text, they undermine reason and restraint and lead ordinarily rational individuals into frenzied extremes of destruction. What on earth could crowds have to do with reconciliation?

\section{Crowds and social identity}

In order to answer this question, we need to rethink the nature of crowd psychology and the process of reconciliation - the link between the two lying

DOI: $10.4324 / 9781003167280-17$ 
in the centrality of social identity processes in both. The concept was introduced to social psychology through the work of Henri Tajfel and John Turner (1986), which posits that at different times, different aspects of the self-system will be salient (in church, religious identity; at a rally, political identity, etc.). Moreover, when different identities are salient, we will behave in terms of the different beliefs, understandings and priorities associated with them: reverent when religious, raucous when political. Over the past four decades, these insights have been applied to the analysis of crowd action (Drury and Reicher 2020; Reicher 1984, 2001, 2017). Not all physical crowds are psychological groups. Sometimes they consist of individuals who have no sense of commonality with others - people crowded onto a train, say. But one sees the contrast when something happens which creates a sense of shared social identity among them - the train breaks down and people begin to view themselves and others as aggrieved commuters. Behaviour changes, people become closer, united in a shared grievance against the train company (Neville et al. 2020).

What happens in such psychological crowds is not that people lose identity, and hence lose control, but rather shift from personal to social identity. Correspondingly, they do not lose all their standards or lose control over their behaviour. Rather, control shifts to collective beliefs, understandings and priorities. This accords with historical studies which show that crowds, including the most extreme and violent crowds, don't do just anything. Rather, crowd action is socially patterned, reflecting collective beliefs, revealing perceptions of who is friend, who is foe, and how they should be treated (Davis 1973; Thompson 1971).

However, it is not just that crowd action reflects social identity, it also serves to create and change social identities (Drury and Reicher 2009; Reicher 1996). One recurring pattern, for instance, arises as a psychologically disparate crowd (say a protest comprising many different groups, some even actively opposed to one another) is treated as if they were all the same by external agents such as the police. This leads to a sense of common fate and can unite those previously opposed within a single emergent category (e.g. Drury and Reicher 2000; Stott and Drury 2000).

Moreover, group identities can be transformed not only for those involved but also for those who observe crowds. As Benedict Anderson (1983) famously argued, large categories like the nation are always "imagined communities", since it would be impossible for all members to assemble together. However, crowds that represent the nation (and other such extended categories) can be seen as the imagined community made manifest.

At the same time, crowd events can be seen as performative acts, deliberately structured in such a way as to create and sustain specific constructions of social identity. This is particularly clear from the literature on festivals and commemorations (e.g. Gillis 1994) which illustrates how these are carefully staged in order to define social relations within the group (who belongs, who takes precedence and who represents us) and between groups. Indeed, where 
understandings of the group change, or where different versions of the group compete at the same time, these are reflected in the changing choreography of collective events (Gelvin 1998; Ozouf 1991).

\section{Reconciliation and social identity}

In this chapter, then, we join together the study of how crowds create social identities with the study of how social identities impact intergroup relations both in terms of reconciling those previously opposed to one another and dividing those previously united. As stated above, we do this in the context of Turkey, a country whose sense of nationhood has always been troubled and contested - and which, as a consequence, remains deeply divided on multiple axes (Poulton 1997). Turkey is split geographically, between a largely rural, traditional and devout Sunni Muslim population and the more urban, modern and secular one. It is also split ethnically, with a long-standing conflict between the state and Kurds, and on religious grounds between Alevis, an often unrecognized heterodox Islamic minority, and the majority Sunni Muslims. Furthermore it is split ideologically, with the political left and right having violently clashed most notably in the years leading up to the 1980 coup.

We examine two of the largest crowd events in recent Turkish history: the 2013 Gezi Park protests and the post 2016-coup "Democracy Watches" gatherings. Both events were bound up with defining what it means to be a citizen of Turkey and involved both elements of unification and of division. However, in contrast to what went before, what was striking in the Gezi Park protests was the way in which they included and brought together previously disparate groups within their definition of nationhood. While reconciliation may not have been the objective of the protests, we discuss how the this provided an opportunity for groups who have long been disconnected and in many cases in conflict with each other (such as Muslim faith groups and LGBT activists) to reconcile.

On the other hand, what was striking about the "Democracy Watches" gatherings, which followed the failed attempt by the military to oust President Recep Tayyip Erdoğan, was the way that they were deliberately aimed at excluding particular groups which, previously, had been accepted as part of the nation. We discuss how this reignited conflict between groups previously involved in a process of reconciliation and also widened the scope of this conflict.

We explore how these outcomes came about by drawing on some of our previous (i.e. Acar and Uluğ 2016; Uluğ and Acar 2015, 2018), and ongoing (i.e. Acar and Reicher manuscript in preparation) studies. The Gezi Park research consists of semi-structured interviews with protest participants in 2013-14 (Acar and Uluğ 2016; Uluğ and Acar 2015), and, later, discussions on the outcomes of the protests in 2016 (Ulug and Acar 2018). The ongoing research consists of analysis of archival media footage of events, as well as 
participant observation at one of the "Democracy Watches" gatherings in Taksim on 21 July 2016 (Acar and Reicher manuscript in preparation; Acar and Sandal Önal forthcoming).

\section{The Gezi Park protests}

\section{The events at Gezi Park}

In 2013, Prime Minister Erdoğan's government initiated a project aimed at redeveloping the Taksim Square area in the centre of İstanbul. Part of pedestrianizing Taksim involved plans to remove Gezi Park, one of the few remaining green spaces in the centre of the European side of the city and replacing it with a building in the style of an Ottoman-style artillery barracks. Strong objections were made about the proposed artillery barracks, as they would remove the Gezi Promenade and also harm mature trees in the area. Furthermore, that the barracks would house a shopping mall was also met with objections, based on the reason that the park was an area used for public recreation being replaced with a consumerist space.

There was also a third, ideological, objection. For many liberals and leftists in Turkey, who claim the heritage of Mustafa Kemal, the founder of the contemporary nation, Taksim is an urban space representing a modern, postOttoman Turkey. In contrast to old İstanbul's restrictive traditional norms, Taksim became the place where men and women could co-exist and participate equally in a secular atmosphere (Gül et al. 2014). The ideological struggles in the 1960s and 1970s brought another layer of symbolism to Taksim, as it became synonymous with socialist ideology and the labour movement. Taksim has, since the 1950s, been the preferred location for political rallies, public meetings and demonstrations. The May Day demonstration on 1 May 1977 were a turning point in Turkish political history. An unknown gunman concealed in a nearby building killed 34 people and injured hundreds of others. The events created a strong symbolic link between Taksim and the leftists in Turkey.

Therefore, the government's intention to reoccupy the square was considered provocation enough, to do so with the construction of a building along pre-modern militaristic lines was even worse and seen as an attempt to erase the symbolic meaning of the square. In occupying Gezi Park, the protesters were doing more than simply opposing a specific urban development. They were defending their vision of a modern nation against what they perceived as Erdoğan's archaic authoritarian vision.

On 28 May 2013, a small group of protesters camped in the park and refused to leave. Images of the police burning protesters' tents and using tear gas to disperse them spread quickly across social media and brought attention to the protests. The size of the protests grew until 31 May when, after an early morning police raid, thousands began to gather in Taksim to protest. Over 1,000 protesters marched on foot over the Bosphorus Bridge from the 
Asian side to the European side of İstanbul to join protesters in Taksim and neighbouring Beşiktaş. On 1 June, the protests spread to Ankara and İzmir, where protesters assembled to show solidarity with those in İstanbul. After being met with police resistance these became centres of occupation in their own right. In the following days, people across the country - in total between 2.5 and 3.5 million - took to the streets in solidarity and to raise their voices regarding the plans for the park. The focus of the protests quickly shifted from environmental and urban policies to a general opposition to the ruling Adalet ve Kalkınma Partisi (AKP - Justice and Development Party) and to then Prime Minister Recep Tayyip Erdoğan.

The park and surrounding Taksim Square remained an occupied space until 11 June, when police entered the square in the harshest crackdown since the start of the movement. On 15 June, the police entered Gezi Park itself and cleared out the protesters, using, as a pretext, a meeting by Prime Minister Erdoğan in another part of İstanbul. After the eviction, there was an increase in protests and demonstrations, with events occurring on and off every weekend throughout mid-2013.

The Gezi Park protests were unique in Turkey for their ability to bring together people who spanned the country's traditional divides, oftentimes with the only common ground being their opposition to Erdoğan and his party. Religious and ethnic minorities (i.e. Kurds, Alevis, Armenians) had a strong presence at the protests, as did LGBT activists. Socialist and the main opposition parties were also present, with some more nationalist groups represented as well.

\section{Common experience, common repression and the production of unity}

The combination of opposition to the AKP, the contextual factors of ongoing events and discontent with government policy, and the police brutality in the streets brought different groups together who oftentimes did not see one another as part of a common community. In some of our previous work (Acar and Uluğ 2016; Acar 2018; Uluğ and Acar 2015, 2018, 2019) Gezi Park protesters described the way that participation in the protests changed their perception of others. A study involving 34 participants from various groups, political parties or institutions pointed to multiple instances of common fate and resultant experiences of togetherness.

At the most basic level, the mere experience of protesting together with others blurred previous boundaries between "us" and "them" and created a common category of protester:

Many different segments came together. You no longer had LGBT, trans, Armenian, CHP, right-wing, or right-wingers. There were a lot of people there to show their reaction to the violent, wild, fascist attitudes of the police or the state. 
In part, this was a process of living in proximity and discovering commonalities that overcame previous assumptions of difference -between feminists and Muslim groups, say, as shown in the following: "Meeting the anti-capitalist Muslims was really interesting ... Iftar meals, the earth tables were unbelievable ... Even though I don't fast, I really looked forward to breakfast because I was going to their earth table" (feminist activist cited in Acar and Ulug 2016). It also came out of the need for mutual support to cope with the basic conditions of the protest. As Ulug and Acar (2018, 2019) show, Gezi Park functioned as an open-air commune. Tents and blankets were shared. Food and water were distributed and a variety of facilities, including a medical clinic and library, were established by the participants. The park and camp area were cleaned by protesters. Lists of items that were needed were posted in the park and on social media, and items would be brought by supporters. If such mutual support is, as we argued above, a consequence of shared social identity, it equally functions as an antecedent, cementing a sense of "we are in this together".

What is more, the various groups managed to work together. That they created an effective and harmonious society in miniature, even with very limited resources, was a source of shared pride which further consolidated a shared sense of identity, mutual respect and transcendence of previous differences:

We showed the world a model of democracy there. "Democracy can be such a thing", we said. We showed "we can go hand in hand with each other, even though we are not like each other, we can exist together in a society by respecting each other".

(Trans activist cited in Uluğ and Acar 2015)

However, while these mutual efforts to survive in harsh times were important, they were framed by the context of repression they had all experienced at the hands of the police. Common repression led to a common category of resistors even among unlikely combinations. Sometimes, this process brought together nationalist Turks and Kurds - previously opposed in armed conflict. As the nationalists found themselves, for the first time, on the receiving end of state brutality, they began to doubt their own previous understandings, to empathize with the Kurdish experience of repression and to question their support for conflict:

Of course, we experienced really interesting things. The gas bombs that were thrown there, the injured people, the oppression; against all this, for example, nationalist Turks would come and say to us "We never understood you, you've experienced this oppression for years ... there were also those who compared themselves to us, "Here in İstanbul's centre, they are calling us the "enemy". I wonder what happened in the east and we didn't see it?"

(Kurdish activist cited in Acar and Uluğ 2016) 
So, whether Muslim or LGBT, nationalist or Kurdish - whichever side of Turkey's entrenched divides one had occupied outside Gezi Park - within the park itself, the protesters were equally subject to police violence and hence came to be on the same side.

This sense of unity in diversity (in face of common adversity) was not just an idea, it was a felt experience. It was embedded in the sensual fabric of the protests. One only had to look at them. The different parties, organizations and groups all had their various flags and banners, the colours that represented them, hanging in the park and on the front of the Atatürk Cultural Centre at the edge of Taksim Square. Walking through the park you could see shades of red of various communist groups, the purple of feminist organizations, combinations of green, red, and yellow for pro-Kurdish groups, not to mention the LGBT rainbow flag and anarchists' black. When reflecting on the protests, some participants would refer to the "many colours of Gezi" and how this patchwork of people came together and coalesced in a common cause.

What is more, the experience was not ephemeral. It did not dissipate as soon as people were evicted from the square. In the years following the protests, many activists still referred to the experiences of togetherness they had at Gezi as a point at which other groups began to embrace their groups' goals for social justice, as well as the new connections that were formed.

We always kept other organizations, other social movements at arm's length. We kind of went along with the feminist movement, the antimilitary movement, ecologic, women's movement, but going arm in arm to a protest is something else ... It's like having a roommate. You can be really good friends with someone but you can have problems when you move in together. [But] at Gezi, we became "roommates" with at least 30 social movements.

(LGBTI activist cited in Uluğ and Acar 2018)

In sum, the Gezi Park protests provide a powerful example of how crowd events can transform the identities of participants. This was achieved through creating a conception of nationhood which, although being rooted in opposition to the AKP government as pursuing an anti-national course, did bring together groups that had previously been opposed to one another and in some cases were even in open conflict with each other.

Of course, this is not a reconciliation process in the conventional sense. No one set out to get on better with anyone. Groups did not go to Gezi Park in order to change their social relations with each other. They didn't evaluate the event in terms of the effects of these relations. But precisely for these reasons Gezi Park is particularly interesting to understand informal, emergent and bottom-up dynamics of reconciliation.

At this point, though, a caveat is in order. We must beware of going from universal condemnation of crowds to universal praise. For, as we shall see 
next, crowds don't only redefine categories to include those who were previously excluded and reverse processes of conflict between these groups. They can equally redraw the boundaries to exclude those who were previously included and hence invigorate intergroup conflict.

\section{The 2016 post-coup "Democracy Watch" gatherings}

\section{The July 2016 coup attempt}

On 15 July 2016, a faction of the Turkish Armed Forces, calling themselves the Yurtta Sulh Konseyi (Peace at Home Council), attempted a coup d'état against Turkey's state institutions. The Peace at Home Council coordinated operations in major cities and key locations in an attempt to remove President Erdoğan. Within a couple of hours, President Erdoğan, who was on holiday in southwest Turkey at the time, gave a FaceTime interview on CNN Türk, during which he called upon his supporters to take to the streets in defiance of the military-imposed curfew. His statement and encouragement to take to the streets was reiterated by other members of his government, including the mayor of Ankara, and soon thousands responded by opposing the military presence around İstanbul and Ankara.

Within a matter of hours, the crowds defeated the coup, and soldiers who took part in the coup attempt surrendered on the Bosphorus Bridge in İstanbul. The AKP regained control of the government and blamed the exiled religious leader Fethullah Gülen and his followers for instigating the coup. But regaining control came at a high price: the event is considered the bloodiest coup attempt in Turkey's political history; 241 people were killed and 2,194 were injured. Following the coup attempt, the government issued a state of emergency that lasted approximately two years. During emergency rule, the government enacted 32 emergency decrees, removing over 100,000 people from public service, and permanently closed nongovernmental organizations, universities and other entities with supposed ties to Gülen or who were otherwise in opposition to the AKP.

\section{The "Democracy Watch" gatherings}

In the weeks following the coup attempt, the government encouraged citizens to continue their presence on the streets with so-called Democracy Watch gatherings organized in major centres and squares in İstanbul and Ankara, including Taksim Square in İstanbul. These nightly meetings were considered a continuation of the civil resistance that took place during the night of 15 July. In contrast with the Gezi Park protests, the Democracy Watches had strong institutional support; food and water were distributed, portable toilets were brought to Taksim Square, and numerous stages were erected, with local radio personalities and others leading the festivities every evening. 
On 7 August 2016, the AKP, together with two other major political parties, the Cumhuriyet Halk Partisi (CHP - Republican People's Party) and the Milliyetçi Hareket Partisi (Nationalist Movement Party), held an anti-coup rally in Yenikap1, İstanbul. Notably, the pro-Kurdish Halkların Demokratik Partisi (HDP - Peoples' Democratic Party) was not invited. The Turkish media announced that millions of people were in attendance at the meeting, although no official estimate exists. President Erdoğan spoke to attendees at Yenikapı Square from a large stage draped with national flags and images of Erdoğan and the founder of the Turkish Republic, Mustafa Kemal Atatürk. Rather than party banners, Erdoğan encouraged participants to carry Turkish flags. In his two-hour speech, Erdoğan extolled the virtues of the citizens who took to the streets on the night of the coup attempt, praising them and their sacrifices.

In contrast to the many different types of flags and banners on display in Taksim during the Gezi Park protests, during the "Democracy Watch" gatherings, the only symbol in Taksim Square was the Turkish flag. One flag took up the entire space of the Atatürk Cultural Centre, with wording that read "Sovereignty belongs to the nation." Beyond the "Democracy Watch" gatherings, this message of unifying under a single national flag could be found all across İstanbul. After the coup attempt, a message on the subway read:

Dear İstanbulites ... Being one and being together, giving your heart and soul in hand, we showed the power of being a nation to the whole world, together we have protected our democracy, our freedom and our homeland. Now is the time for our flag to wave proudly, let's hang our moon and star flag from our workplaces and our homes, and let's be one and be together in its shadow.

(Acar and Sandal Önal forthcoming)

The AKP government also put the coup attempt and the resistance against it into a historical framework. The "Democracy Watch" gatherings utilized familiar tropes related to Turkey's 1919-23 War of Independence, creating and perpetuating the myth of a "second founding" after 2016 (Konya 2020). Therefore, the crowds that rose up to prevent the coup were lauded as saviours of the country and of democracy. They were consistently honoured in the national media through personal stories and the traumas that were experienced on the night of the attempted coup. Those who died received official "martyr" status, and the resistance of that night became a war comparable to the American and French Revolutions (Taş 2018). Erdoğan stated that " 15 July is the second War of Independence for the Turkish nation. Let us know it like that. They [threatened] us with Sèvres in 1920 and persuaded us to [accept] Lausanne in 1923' (Hürriyet Daily News 2016). In doing so, he created a narrative that continued the one that created the Turkish Republic, whereby Western Imperialism attempts to "destroy" the Turkish state, but it 
is the people that resist and prevent its destruction. Turkish history texts were revised to include the events, and national landmarks and squares were renamed to keep the memory of the coup attempt alive.

Critically, the notion of a "coup" relies not only on an external enemy but also on an internal enemy. It therefore serves not only to bring the nation together against foreign foes, but also against those within the nation who are characterized as the dupes or collaborators of these foes. One should note, though, that in different coups the nature of the internal enemy (and hence the identity of those who need to be excluded) changes. During the 1980 coup the target was the "anarchists" (referring mostly to young politicized leftists). In this case the focus was the "terrorists". In practice this meant anyone who opposed the AKP and President Erdoğan. Hence, although the ostensible focus of the event was one of inclusion and unification within the nation, the Democracy Watches served to narrow the definition of the category so as to exclude many groups which, previously, could be included as Turkish.

So, while at one level the Democracy Watches and the Gezi Park protests were similar in that they both involved elements of both inclusion and exclusion, at another level they were diametrically opposed. The Gezi Park protests were ostensibly an act of opposition (rejecting the AKP as representing the nation) but one that brought together opposed groups in an extended definition of the nation. The Democracy Watches were ostensibly acts of unification (bringing the nation together after experiencing trauma) but nevertheless excluded previously reconciled groups from a narrowed definition of the nation.

This contrast was visible at many levels. We have seen how Gezi Park was a riot of different colours and styles and flags manifesting "unity in difference" (Konya 2020, p. 18). By contrast, the "Democracy Watches" gatherings were uniformly uniform: a single colour (red), and a single flag (the Turkish national standard) for all. Whereas the Gezi Park protests were bottom-up, encouraging a multitude of voices and emphasizing the need to learn from one another, the "Democracy Watch" gatherings were rigidly topdown, allowing only one voice, namely that of Erdoğan and his AKP. Indeed, the contrast between the two events is not just an analytic claim, it is emphasized by Erdoğan himself:

One of the biggest heroes of the July 15 was our youth ... Immediately taking action, they stood up against tanks and retrieved the areas invaded by the coup plotters ... Those coming there that night were not the youth of Gezi Park. Those who came there that night were the ones who loved the country.

(Presidency of the Republic of Turkey 2017)

Time and again during the "Democracy Watch" events, those present and those who opposed the plotters on the night of the coup are described as 
"the nation", while others are described either as "terrorists" or as "terrorist supporters". Moreover, the crowd participated actively in this construction, sharing their personal stories, booing when anyone was named as an enemy of the state (Acar and Reicher in progress). In this way Erdoğan, the AKP leadership and their followers co-created an exclusive boundary to Turkish nationhood.

Having said this, the prototypical "terrorist other" is identified with the Kurds and the pro-Kurdish political parties (notably the pro-Kurdish HDP, even though they held the third largest percentage of votes garnered by the four major parties). While other opposition parties such as the CHP were invited to participate in the Democracy Meeting (albeit on Erdoğan's terms), the HDP was not, and when asked why Erdoğan replied:

As I always say, I can meet any opinion, any group that has the four principles: One homeland, one nation, one state, one flag ... I do not come together with those who are involved in terrorism and are intertwined with terrorism. This is my red line.

(Diken 2016)

Just as what happened in Gezi Park did not stay in Gezi Park but impacted longer-term social relations, the same is true of the "Democracy Watch" gatherings - although this time they undermined rather than promoted processes of reconciliation. Prior to the coup, the government was involved in a peace process with the Partiya Karkerên Kurdistan (PKK - Kurdish Workers' Party). It was the calm brought about by this process in a region that had been marked by conflict for decades that allowed the HDP to gain popularity as a pro-minority and egalitarian party. The "Democracy Watch" gatherings were part of a process, however, which positioned Erdoğan's opponents as enemies of the state and, hence, as illegitimate participants in the political and social sphere.

This had begun pre-coup after the HDP won 80 seats in the June 2015 general election and deprived Erdoğan's AKP of an overall majority. Mounting conflict led to the collapse of the peace process with the PKK. As we have seen, the "Democracy Watch" gatherings were used to broaden the definition of the "terrorist other" to include the HDP. Subsequently, it was broadened still further to include all those who criticized Erdoğan's Kurdish policy, with many of the 1,128 intellectuals and academics, who, in January 2016, had signed a "peace petition", being prosecuted as "terrorist sympathizers". In effect, to oppose Erdoğan was to be a "non-citizen" (Acar and Coşkan 2020).

\section{Conclusion}

The two cases we have considered in this chapter highlight the different ways in which crowd events can impact upon how boundaries of identity are drawn and intergroup histories rewritten. 
In sum, the mass rallies of August 2016, like those witnessed three years earlier in Gezi Park, served as a performative construction of group boundaries - and, more specifically, of Turkish national identity. As acts of boundary making both necessarily involved inclusion and exclusion, unification and differentiation. But whereas the Gezi Park protests served to broaden the conventional boundaries of inclusion, the "Democracy Watch" gatherings served to narrow down previous definitions. Correspondingly, whereas the Gezi Park protests promoted reconciliation (including between nationalists and Kurds), the August 2016 rallies disrupted reconciliation with the Kurds and accentuated existing fault lines in society between Erdoğan's mainly traditional and rural base and his urban liberal opponents so as to produce new forms of conflict.

The overall point that comes out of this is that reconciliation may well be a matter of category relations but that, more basically, category relations are a function of how category boundaries are drawn - that is, how we define who is "us" and who is "them". And, as recent research has shown, crowd events are one of the major sites in which these definitions can change (Drury and Reicher 2020). That is not to say that crowds always produce such change. Indeed, many crowds serve to confirm existing social relations. Indeed, there is an abundance of literature on how commemorations, festivals and other mass phenomena are central to telling us who we are and who is "us" (e.g. Gillis 1994). But that doesn't mean that these are irrelevant for reconciliation, simply that they confirm rather than change existing prospects for reconciliation.

One final comment based on a final contrast between the Gezi Park protests and the "Democracy Watches" rallies: as we stressed earlier, the Gezi Park crowds were not intended as a reconciliation process, but they nevertheless led to a process of reconciliation. The "Democracy Watch" gatherings, however, were very deliberately choreographed in order to narrow Turkish nationhood around the figure of the president. Yet the effects came about irrespective of whether they were intended to or not. It is simply that, if we can understand the path from crowd dynamics to categorical change to the prospects for reconciliation, we are in a better position to harness those dynamics for the sake of resolving old antagonisms rather than creating new ones.

\section{References}

Acar, Yasemin Gülsüm. "Gezi'den Sonra Ne Oldu? Güçlenmenin, Politikleşmenin ve Örgütlenmenin Kolektif Eylemlerdeki Rolü [What happened after Gezi? The role of empowerment, politicization and organization in collective action]". Turkish Psychology Articles, vol. 21, 2018, pp. 62-81.

Acar, Yasemin Gülsüm, and Canan Coşkan. "Academic activism and its impact on individual-level mobilization, sources of learning, and the future of academia in Turkey”. Journal of Community \& Applied Social Psychology, vol. 30, no. 4, 2020, pp. 388-404, https://doi.org/10.1002/casp.2455. 
Acar, Yasemin Gülsüm, and Elif Sandal Önal. "Military coups in Turkey and their effect on political culture and national identity". Intergroup Relations in Turkey, Abingdon, Routledge and CRC Press, forthcoming.

Acar, Yasemin Gülsüm, and Stephen D. Reicher. How crowds stop social change: An analysis of pro-government democracy meetings in post-coup Turkey. Manuscript in preparation.

Acar, Yasemin Gülsüm, and Özden Melis Uluğ. "Examining prejudice reduction through solidarity and togetherness experiences among Gezi Park activists in Turkey". Journal of Social and Political Psychology, vol. 4, no. 1, 2016, pp. 166179, https://doi.org/10.5964/jspp.v4i1.547.

Anderson, Benedict. Imagined communities: Reflections on the origin and spread of nationalism. London, Verso, 1983.

Davis, Natalie Zemon. "The rites of violence: Religious riot in sixteenth-century France”. Past \& Present, vol. 59, no. 1, 1973, pp. 51-91, https://doi.org/10.1093/pa st/59.1.51.

Diken. "HDP'yi Yenikapı'ya çağırmayan Erdoğan: Terörle iç içe olanlarla bir araya gelmem". 7 August 2016, www.diken.com.tr/hdpyi-yenikapiya-da-davet-etmeye n-Erdoğan-terorle-ic-ice-olanlarla-bir-araya-gelmem/.

Drury, John, and Stephen D. Reicher. "Collective action and psychological change: The emergence of new social identities". British Journal of Social Psychology, vol. 39, no. 4, 2000, pp. 579-604, https://doi.org/10.1348/014466600164642.

Drury, John, and Stephen D. Reicher. "Collective psychological empowerment as a model of social change: Researching crowds and power". Journal of Social Issues, vol. 65, no. 4, 2009, pp. 707-725, https://doi.org/10.1111/j.1540-4560.2009.01622.x.

Drury, John, and Stephen D. Reicher. "Crowds and collective behaviour". Oxford research encyclopedia: Psychology. Oxford, Oxford University Press, 2020, doi:10.1093/acrefore/9780190236557.013.304.

Gelvin, James L. Divided loyalties: Nationalism and mass politics in Syria at the close of empire. Berkeley, University of California Press, 1998.

Gillis, John R. Commemorations: The politics of national identity. Princeton, NJ, Princeton University Press, 1994.

Gül, Murat, John Dee, and Cahide Nur Cünük. "İstanbul's Taksim Square and Gezi Park: The place of protest and the ideology of place". Journal of Architecture and Urbanism, vol. 38, no. 1, 2014, pp. 63-72, https://doi.org/10.3846/20297955.2014. 902185.

Hürriyet Daily News. "Erdoğan's remarks on treaty that formed modern Turkey irk opposition". 29 September 2016, www.hurriyetdailynews.com/Erdoğans-rema rks-on-treaty-that-formed-modern-turkey-irk-opposition-104386.

Konya, Nazlı. "Making a people: Turkey's 'Democracy Watches' and Gezi-envy". Political Theory, 2020, https://doi.org/10.1177/0090591720981904.

Le Bon, Gustave. The crowd: A study of the popular mind. 1895. Reprint. New York, Viking, 1960.

Neville, Fergus G., Novelli, John Drury, and Stephen D. Reicher. "Shared social identity transforms social relations in imaginary crowds". Group Processes \& Intergroup Relations, 2020, https://doi.org/10.1177\%2F1368430220936759.

Ozouf, Mona. Festivals and the French Revolution. Cambridge, MA, Harvard University Press, 1991.

Poulton, Hugh. The top hat, the grey wolf and the crescent. New York, New York University Press, 1997. 
Presidency of the Republic of Turkey. Our youth were on the front line against July 15 coup attempt. 28 May 2017,www.tccb.gov.tr/en/news/542/77389/our-youth-wer e-on-the-front-line-against-july-15-coup-attempt.

Reicher, Stephen D. “'The Battle of Westminster': Developing the social identity model of crowd behaviour in order to explain the initiation and development of collective conflict”. European Journal of Social Psychology, vol. 26, no. 1, 1996, pp. 115-134, https://doi.org/10.1002/(SICI)1099-0992(199601)26:1<115:AID-EJSP740>3.0.CO;2-Z.

Reicher, Stephen D. “'La beauté est dans la rue': Four reasons (or perhaps five) to study crowds". Group Processes \& Intergroup Relations, vol. 20, no. 5, 2017, pp. 593-605, https://doi.org/10.1177/1368430217712835.

Reicher, Stephen D. "The psychology of crowd dynamics". Blackwell handbook of social psychology: Group processes, edited by Michael A. Hogg and Scott Tindale, Oxford, Blackwell, 2001, pp. 182-208.

Reicher, Stephen D. "The St. Pauls' riot: An explanation of the limits of crowd action in terms of a social identity model". European Journal of Social Psychology, vol. 14, no. 1, 1984, pp. 1-21, https://doi.org/10.1002/ejsp.2420140102.

Stott, Clifford, and John Drury. "Crowds, context and identity: Dynamic categorization processes in the "poll tax riot"”. Human Relations, vol. 53, no. 2, 2000, pp. 247-273.

Thompson, Edward P. "The moral economy of the English crowd in the eighteenth century". Past \& Present, no. 50, 1971, pp. 76-136.

Tajfel, Henri, and John C. Turner. "The social identity theory of intergroup behaviour". Psychology of intergroup relations, Chicago, Hall Publishers, 1986.

Taş, Hakk1. "The 15 July abortive coup and post-truth politics in Turkey". Southeast European and Black Sea Studies, vol. 18, no. 1, 2018, pp. 1-19, https://doi.org/10. 1080/14683857.2018.1452374.

Uluğ, Özden Melis, and Yasemin Gülsüm Acar. "Names will never hurt us': A qualitative exploration of Çapulcu identity through the eyes of Gezi Park protesters". British Journal of Social Psychology, vol. 58, no. 3, 2019, pp. 714-729, https://doi. org/10.1111/bjso.12305.

Uluğ, Özden Melis, and Yasemin Gülsüm Acar. "We are more than alliances between groups': A social psychological perspective on the Gezi Park protesters and negotiating levels of identity". "Everywhere Taksim": Sowing the seeds for a new Turkey at Gezi. Amsterdam, Amsterdam University Press, 2015.

Uluğ, Özden Melis, and Yasemin Gülsüm Acar. "What happens after the protests? Understanding protest outcomes through multi-level social change". Peace and Conflict: Journal of Peace Psychology, vol. 24, no. 1, 2018, p. 44, https://doi.org/10. 1037/pac0000269. 